Rev Biomed 2000; 11:309-310.

\title{
Contribución a un entendimiento de las enfermedades mentales.
}

\author{
Carta al Editor
}

Jesús Quintanilla-Osorio.

Coordinación de Regulación Sanitaria, Jurisdicción Sanitaria 1, Servicios Estatales de Salud de Quintana Roo. Chetumal, Q. Roo, México.

En un concepto estrictamente axiológico, un hombre es normal, en la medida que acata las costumbres y códigos de comunicación de un grupo determinado. La palabra normal, proviene del griego "regla", y por esto, se considera un patrón común de conducta el seguir las conveniencias sociales.

De acuerdo al psicólogo Erich Fromm, es "normal" quien es capaz de participar en el proceso de producción económica de su sociedad, y comúnmente, se equivale ser normal a ser sano.

La Organización Mundial de la Salud (OMS), define "la salud como un estado de bienestar físico, mental y social, no solamente como la ausencia de enfermedad"(1). De esto, se desprende que la salud mental es un estado sujeto a fluctuaciones provenientes de factores biológicos y sociales, donde el individuo se encuentra en condiciones de conseguir los satisfactores de sus instintos antagónicos, así como de formar y mantener relaciones armoniosas con sus congéneres, participando constructivamente en cambios que puedan sucederse en un ambiente físico y social.
La actuación considerada normal de una persona debe de ser vista dentro de su contexto sicosocial. En nuestra sociedad, la anormalidad es un sinónimo de locura, por un evidente desconocimiento del concepto de las patologías mentales. Estas alteraciones de la conducta no son simplemente las reacciones de estrés que se manifiestan en un día difícil cuando hasta el más ecuánime se muestra descontrolado. Tampoco son nuestras propias interpretaciones de lo que es femenino o masculino de acuerdo a los patrones comunes a la sociedad, como el considerar que un hombre lavando ropa o preparando un guiso está asumiendo papeles femeninos. Margaret Mit estudió en Samoa a una tribu donde las mujeres cazaban, mientras los hombres tejían redes y cuidaban a los niños. Tal conducta hubiera sido vista ridícula en nuestra rigidez de papeles sociales. La enfermedad mental es un conjunto de signos y síntomas que siguen una evoluación muy definida, debido a una causa común, específica, localizada en el cerebro. Se puede establecer una hipótesis de su origen (etiología), e incluso las fases de la enfermedad,

Solicitud de sobretiros: T.V.S. Jesús Quintanilla-Osorio, Tlaxcalaltongo 250, Col. V. carranza entre Carranza y San Salvador, Chetumal, Q. Roo., México. 


\section{J Quintanilla-Osorio.}

según el nivel de avance que tenga. Resulta interesante que el terreno de la mente, "la potencia espiritual del alma", según el Dr. Gaspar Baquedano, del Hospital Psiquiátrico "Yucatán", parece estar rodeado de fantasmas de tabúes, de esas prohibiciones atávicas donde se tiene miedo a lo que se desconoce, y la ciencia médica ha descorrido el velo de tales misterios aparentes, presentando como problemas humanos aquellos que en el medievo justificaron la cacería de brujas por considerar posesas a mujeres que sufrían trastornos de personalidad o de serias afectaciones mentales. Es hora de participar activamente en esta corriente donde se deben sacar a la luz de la razon todos esos padecimientos mentales con un enfoque clínico, bajo conceptualizaciones y etiologías muy bien definidas, con marcos de referencia indubitables, bajo el consenso de especialistas en la materia, para contribuir a derribar el muro de intolerancia que aún persiste en este tema. Es tiempo de actuar.

Palabras clave: Enfermedades mentales, salud mental.

\section{REFERENCIA.}

1.- Programa de formación e incorporación de técnicos y auxiliares en salud, Secretaría de Salud, México, 1994. 